\title{
Technè
}

La science au service de l'histoire de l'art et de la préservation des biens culturels

48 | 2019

Les couleurs de l'Antique

\section{A group of painted funerary monuments from Hellenistic Alexandria in the Metropolitan Museum of Art}

Un ensemble de monuments funéraires peints provenant de l'Alexandrie

hellénistique au Metropolitan Museum of Art

Dorothy H. Abramitis and Mark B. Abbe

\section{(2) OpenEdition}

\section{Journals}

Electronic version

URL: https://journals.openedition.org/techne/2238

DOI: $10.4000 /$ techne.2238

ISSN: 2534-5168

\section{Publisher}

C2RMF

\section{Printed version}

Date of publication: 31 December 2019

Number of pages: $60-71$

ISBN: 978-2-11-152831-4

ISSN: 1254-7867

\section{Electronic reference}

Dorothy H. Abramitis and Mark B. Abbe, "A group of painted funerary monuments from Hellenistic Alexandria in the Metropolitan Museum of Art", Technè [Online], 48 | 2019, Online since 01 July 2021, connection on 03 April 2022. URL: http://journals.openedition.org/techne/2238 ; DOI: https://doi.org/ 10.4000/techne.2238

\section{(c) (†) $\ominus$}

La revue Technè. La science au service de l'histoire de l'art et de la préservation des biens culturels est mise à disposition selon les termes de la Licence Creative Commons Attribution - Pas d'Utilisation Commerciale - Pas de Modification 4.0 International. 


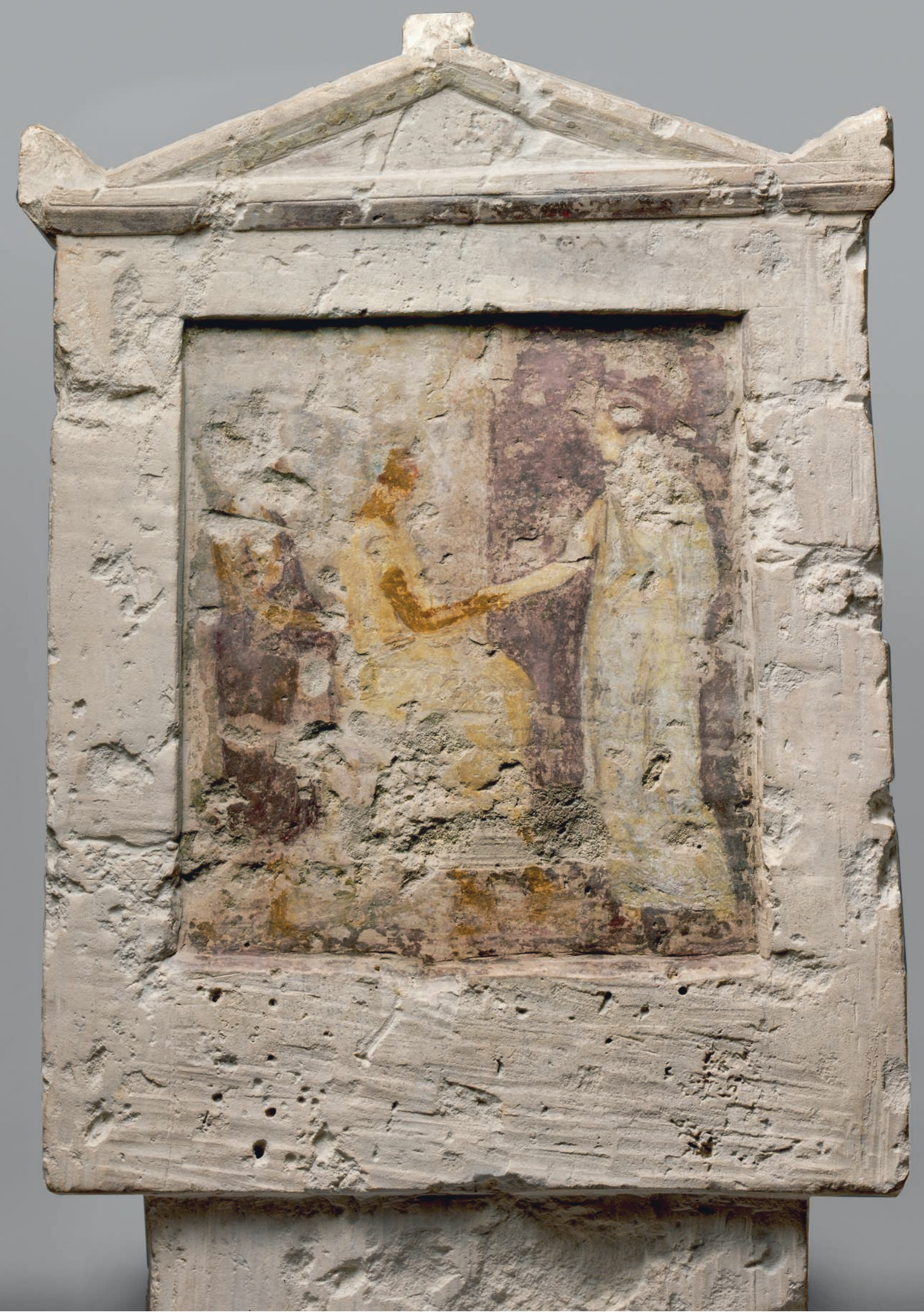

Fig. $1 \mathrm{~b}$. Painted limestone funerary stele with a seated man and two standing figures, late 4th-early 3rd century B.C. (04.17.2) (H. $74.3 \mathrm{~cm}$, W. $47.6 \mathrm{~cm}$, D. $10.8 \mathrm{~cm}$ ). () The Metropolitan Museum of Art, Photographer: J. Trujillo. 
Dorothy H. Abramitis

Mark B. Abbe

\section{A group of painted funerary monuments from Hellenistic Alexandria in the Metropolitan Museum of Art}

Un ensemble de monuments funéraires peints provenant de l'Alexandrie hellénistique au Metropolitan Museum of Art
Abstract. Examination and scientific analysis have elucidated the
well-preserved figural painting on a collection of limestone
funerary stelai and loculus slabs from Alexandria, Egypt, dating
from the late 4 th to $3 r d$ centuries B.C. This paper presents new
information about the preparation, design, and technique of these
paintings, which display a lead white ground preparation, both
incised and black preliminary drawing, and a masterful elaborate
multi-layered painting process to build up color. The paintings'
generally bright colorful palette employs a wide range of pigments
attested elsewhere in the classical Greek palette, and features,
notably, the extensive use of mimetite, a geologically rare yellow
lead arsenate mineral, uncommon in Greek and Roman painting
and unknown in earlier Pharaonic painting traditions.
Keywords. Painting, Greek, Hellenistic, Alexandria, Egypt, Ptolemaic, limestone, stelai, loculus slabs, mimetite, pigment.
Résumé. Examen et analyses scientifiques ont permis de faire la lumière sur les peintures figurées, remarquablement conservées, qui ornent un ensemble de stèles et de plaques de loculus funéraires alexandrines en pierre calcaire, exécutées entre la fin du IV siècle et le III siècle avant J.-C. La présente étude apporte de nouvelles informations sur la préparation, la conception et la technique de ces peintures, où l'on observe une couche d'apprêt en blanc de plomb, un tracé préliminaire alliant incision et dessin au trait noir, et un jeu savant de couleurs montées par superposition de couches picturales. La palette généralement vive comprend un large éventail de pigments attestés ailleurs pendant la période classique; on y remarque l'emploi de mimétite, un arséniate de plomb jaune qui est un minéral rare, peu employé dans la peinture grecque et romaine, et inconnu dans les traditions pharaoniques antérieures.

Mots-clés. Peinture grecque, hellénistique, Alexandrie, Égypte, ptolémaïque, calcaire, stèle, plaque de loculus, mimétite, pigment.
In 1904, the Metropolitan Museum of Art acquired a group of six Greek funerary monuments from Alexandria dating from the late 4 th and 3rd centuries B.C. featuring well-preserved painted figural scenes (fig. 1 a-f). Reportedly from a communal tomb discovered in the city's eastern necropolis in 1884, these works form a rare and important collection of extant Greek painting from the early Hellenistic period of Ptolemaic Alexandria that have remained little investigated since Blanche R. Brown's Ptolemaic Paintings and Mosaics and the Alexandrian Style (1957). This paper clarifies aspects of the origins of the group since Brown's study and presents new technical research on this important and often overlooked examples of elaborate funerary painting from the Ptolemaic capital.

\section{Alexandrian origins: clarifications}

All of the Museum's six painted monuments were acquired together in Alexandria in early 1884 by Elbert E. Farman, the American Consul General to Egypt. During a diplomatic mission to the city, Farman was shown by a local antiquarian a recently discovered hypogeum tomb in an area by the sea approximately one mile east of the medieval city walls ${ }^{1}$. In the late 19th century, a large number of ancient tombs were revealed in this region, the Ibrahimieh district of the modern city, in a large poorly understood group of early and mid-Ptolemaic extra-urban necropoleis in the area. Like the better understood western cemeteries of Alexandria, these contained both surface funerary monuments - stelai, altars, and columns - and a concentration of subterranean chamber and gallery tombs, or hypogea, cut into the soft local limestone to house

Dorothy H. Abramitis, Conservator, Sherman Fairchild Center for Objects Conservation, The Metropolitan Museum of Art, New York, New York (de.abramitis@metmuseum.org). Mark B. Abbe, Associate Professor of Ancient Art, University of Georgia, Athens, Georgia (abbe@uga.edu). 


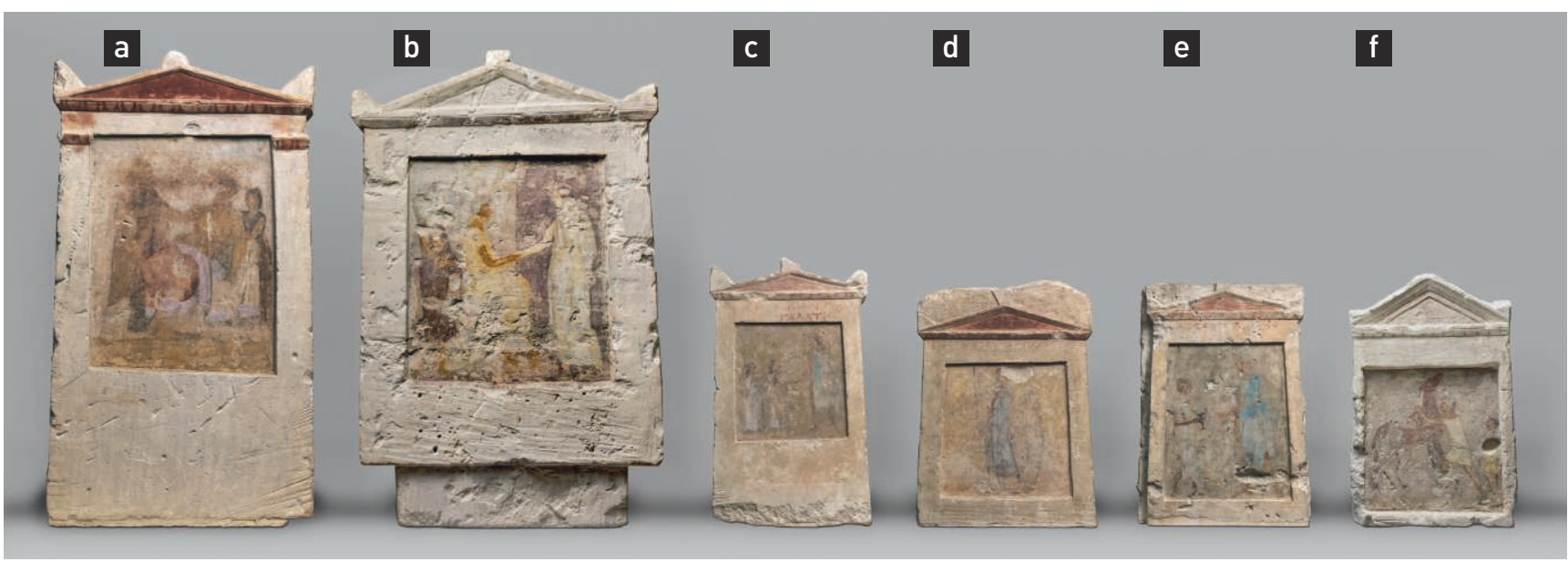

Fig. 1 a-f. Group of painted limestone funerary monuments from Alexandria, Egypt, late 4th-2nd half of 3rd century B.C. Left to right: a. Stele with a woman in childbirth $(04.17 .1)(\mathrm{H} .75 .9 \mathrm{~cm}, \mathrm{~W} .42 .5 \mathrm{~cm}$, D. $11.4 \mathrm{~cm})$; b. Stele with a seated man and two standing figures $(04.17 .2)$ (H. $74.3 \mathrm{~cm}$, W. $47.6 \mathrm{~cm}$, D. $10.8 \mathrm{~cm})$; c. Funerary slab with a soldier and two girls $(04.17 .4)(\mathrm{H} .41 .9 \mathrm{~cm}, \mathrm{~W} .24 .4 \mathrm{~cm}$, D. $9.8 \mathrm{~cm})$; d. Funerary slab with a soldier standing at ease $(04.17 .5)(\mathrm{H} .39 .4 \mathrm{~cm}$, W.
$29.5 \mathrm{~cm}$, D. $9.5 \mathrm{~cm})$; e. Funerary slab with a soldier taking a kantharos from his attendant $(04.17 .6)(H .37 .6 \mathrm{~cm}$, W. $24.4 \mathrm{~cm}$, D. $8.6 \mathrm{~cm})$; f. Funerary slab with a man controlling a rearing horse $(04.17 .3)$ (H. $39.4 \mathrm{~cm}$, W. $26.7 \mathrm{~cm}$, D. $7.3 \mathrm{~cm})$. The Metropolitan Museum of Art, Gift of Darius Odgen Mills, 1904, 04.17.1-6. All images (C) The Metropolitan Museum of Art, 04.17.01, 04.17.4-.6. Photographer: B. Schwarz; 04.17.2-.3, Photographer: J. Trujillo. multiple burials. The walls of these hypogea typically contained rows of narrow niches, or loculi, carved out for individual burials, which were sealed with painted limestone funerary slabs ${ }^{2}$.

The tomb Farman entered in early 1884 and later described in correspondence is otherwise archaeologically unrecorded. He described it as a room, or vault, about eight feet high and fourteen feet square, located at a depth of approximately twenty feet from the surface. When he was shown the tomb by his unnamed local antiquarian, he noted that in the center of the hypogeum "were standing, some on
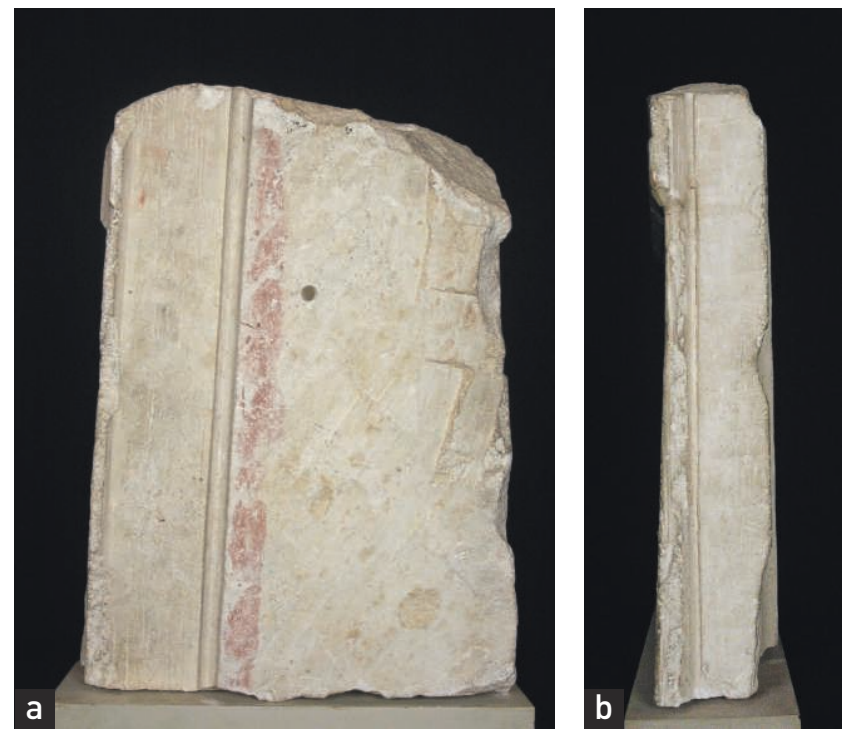

Fig. $2 a-b$. Reverse and side view of the funerary slab with a soldier standing at ease (fig. $1 \mathrm{~d}$ ) carved from a cornice block of an earlier (tomb?) construction. The Metropolitan Museum of Art, 04.17.5. (c) M. Abbe. top of the others, about fifty funereal urns, or vases; and leaning against the walls were a considerable number of painted stelai, or tablets. The tablets were from a foot to two and half feet high, and from ten to sixteen inches broad 3 ". Farman acquired the six well-preserved "stelai" (actually two stelai and four funerary loculus slabs) and the intact Hadra cinerary urns, leaving the remainder. Upon his return to the United States in 1885, Farman loaned his new collection of painted monuments to the Metropolitan Museum for exhibition until 1904 when Darius O. Mills purchased the group from Farman and formally presented them as a gift to the Museum.

Despite Farman's description of the tomb in 1884, the provenance of these objects has often been confused with another large tomb discovered in the Ibrahimieh necropolis a year later, in 1885 , conventionally known as the Tomb of the Mercenaries and/or the Soldiers's Tomb, due to the preponderance of monuments commemorating foreign mercenaries $^{4}$. Although Blanche R. Brown mistakenly conflated the objects from Farman's tomb with these later finds in her 1957 stylistic study of the Metropolitan's group, archival research at both the Metropolitan Museum of Art and the Louvre, which acquired the majority of objects taken from the Tomb of the Mercenaries, has since securely determined that Farman's tomb was a distinct tomb, though from the same necropolis and sharing common features to other reported hypogea in the vicinity ${ }^{5}$.

\section{The objects and their scientific study}

The Metropolitan's objects are composed of two types of funerary monuments. The two larger pieces are free-standing stelai (fig. 1 a-b), one of which preserves its original carved tenon for insertion into a base. These were probably originally displayed 
in a family grave plot either above ground or within large family hypogea. On the large recessed area of the stelai, the deceased is represented in intimate indoor private domestic scenes with family members. With their emphasis on kin and household, such images are most widespread in Alexandria in the late 4th and early 3rd centuries B.C. when the city's Greek settlers brought with them the visual traditions of family-focused funerary images wellknown from Athenian grave stelai of the late Classical period. The other four smaller objects are loculus slabs (fig. 1 c-f), typical of the more modest communal chamber graves of Alexandrian hypogea. These paintings feature the deceased in a group or in isolation and generally emphasize their subject's public role and function in society in a commemorative language that emerges in the funerary sphere across the Greek world in the 3rd century. These paintings feature representations of social status and ethnic identity, such as the loculus slabs of Galatian and Thessalian immigrant mercenaries who increasingly served in the Ptolemaic armies in this period (fig. 1 c-e). Devoid of notable local family lineage (few have a patronymic), the deceased are explicitly identified by their ethnic group in inscriptions and proudly display distinctions of military rank and specialization through attributes - spears, shields and colored military cloaks - in a manner often inspired by the contemporary civic honorific statuary ${ }^{6}$.

The composite nature of the

Metropolitan's funerary monuments and their reported formal presentation to E. E. Farman for acquisition suggest they were a market-oriented assemblage, rather than an intact archaeological group. While presumably all of the material originates from necropoleis within the larger Ibrahimieh area, the precise details of their archaeological origins and ancient display contexts remain predictably obscure. Examination however reveals that at least two of the loculus slabs were carved from recycled masonry blocks: one was generated from projecting terminus of a cornice block from a small architectural construction, perhaps a recycled masonry tomb (fig. 2 a-b), and another (fig. 1 f) has a finely smoothed reverse from its easier use as a masonry ashlar. The excellent condition of the group's paintings stems from their protection since Antiquity presumably within the stable environment of the necropoleis' ancient hypogea, but it may be noted that most of the large funerary stelai preserving ancient panting from this period do so because they were relatively quickly redeployed in later ancient masonry constructions that fortuitously protected their fragile painted surfaces (e.g. Demetrias, Vergina, and Chersonessos ${ }^{7}$ ).

The technical examination and scientific characterization of painting on the Metropolitan's group of Alexandrian funerary monuments has revealed significant information about both the complex painting process and the range of pigments employed (table 1 , see page 69 ), through magnification (5-200X), imaging in multiple lighting conditions (fig. 3 a-d, fig. 4 a-d), in situ X-ray fluorescence spectroscopy, and analysis of microsamples by polarized light microscopy, Raman spectroscopy, UV-visible absorption spectroscopy and X-ray microdiffraction spectroscopy ${ }^{8}$. 

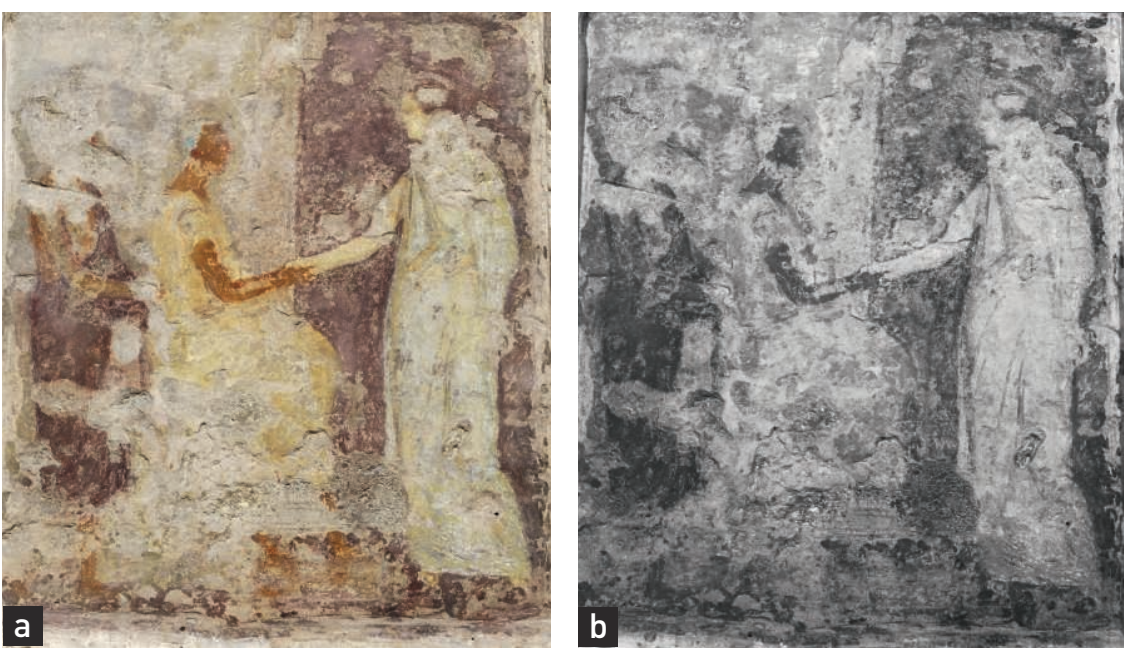

the application of pigments. Cerussite has also been identified on the painted limestone monuments from Alexandria in the Louvre ${ }^{10}$. The small amounts of challacolloite identified presumably reflect both variation in the production process and the reaction of the lead carbonate with an aqueous chloride in the burial environment. No celestine has been identified in the ground material, as reported to have been found on the Alexandrian loculus slabs in the Louvre, where this mineral has been identified as a deliberately added white pigment ${ }^{11}$.

Upon the prepared lead white
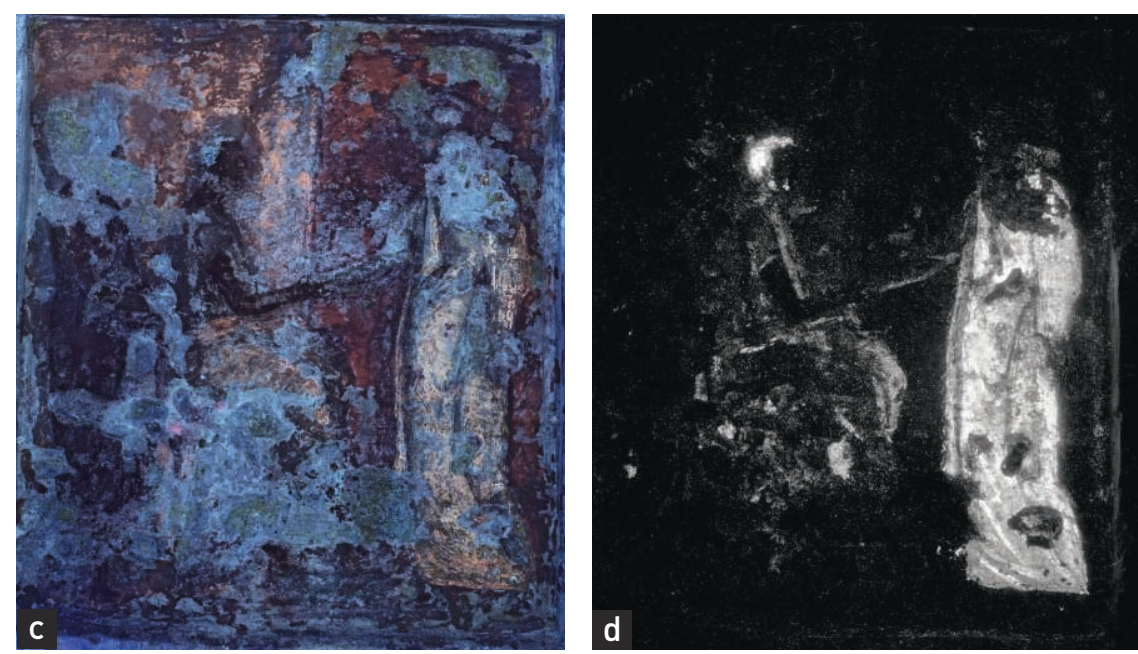
ground of the recessed panel, the figural compositions were quickly sketched. Incision on the ground using a pointed tool is limited to the two larger stelai and consists of a few lines to anchor key figural passages of the multi-figured compositions within the large picture plane, such as on the stele of the woman in childbirth where the outline of central torso and arms of the reclining woman are defined (fig. 7 a-b). Both the stelai and loculus slabs display extensive preliminary drawing executed in carbon black in all of the figural paintings. This is now readily visible due to paint loss on worn

Fig. 4 a-d.a. Picture panel of stele with a seated man and two standing figures (fig. 1 b). (c) The Metropolitan Museum of Art/B. Schwarz; b. Infrared-reflected image (IRR); c. Ultraviolet-induced luminescence image (UVL); $d$. Visible-induced infrared luminescence image (VIL). Images b-d @ The Metropolitan Museum of Art/D. Abramitis. areas, such as on the loculus slab with a soldier holding a spear and shield (fig. $1 \mathrm{~d}$, fig. 5), but is also evident on well-preserved passages and remained partially visible in areas after the applic-

\section{Substrate, ground preparations, and preliminary drawings}

All six monuments were carved from a cream-colored aragonitic limestone ${ }^{9}$, which has the extensive macroscopic porosity that is characteristic of the local geology of Alexandria. As the visual focus of these monuments was the figural painting set within the flat recessed panel chiseled into the front, any geological flaws on the front of the panel were filled with a coarse-grained plaster to obtain a more even, uniform surface (see middle to bottom center of fig. 4 a, fig. 5 , fig. 8 a). A white ground appears to have been subsequently applied within each recessed picture panel in preparation for the figural painting (fig. 6 a-b). Materials analyses (in situ X-ray fluorescence spectroscopy, polarized light microscopy, Raman spectroscopy, and X-ray microdiffraction) indicate this ground material is composed of an abundance of cerussite and minor amounts of challacolloite. This opaque lead white ground provided a brilliant, highly reflective and dense surface for ation of color, such as in the supporting female figures on the stele with the woman in childbirth (fig. 1 a, fig. 3 a). Thick black lines of varying widths defined the outline of figures, while thinner, rapid strokes economically sketched internal features, garments and drapery folds. The quick, fluid nature of both the incision and preliminary "drawing" clearly reveal the artisans' familiarity and masterful fluency with the often-formulaic compositions.

\section{The techniques and technological styles of the paintings}

The absence of lime plaster in the ground layer strongly suggests that the paintings were generally executed in a secco technique with the pigments and colorants bound in an organic medium. The ancient (likely multiple) media used in the paintings however remains undetermined. Although upon first inspection, the unusually well-preserved painted 


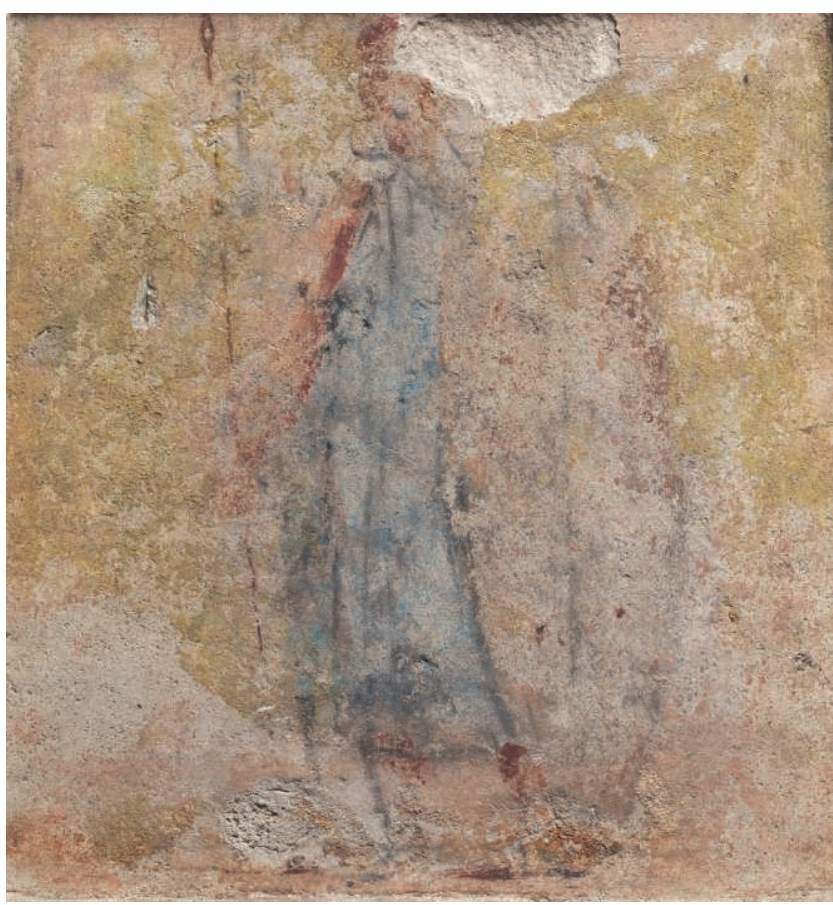

Fig. 5. Picture panel of funerary slab with a soldier standing at ease (fig. $1 \mathrm{~d}$ ) with black outline underdrawing visible. (C) The Metropolitan Museum of Art/B. Schwarz.

surfaces of Metropolitan's stelai and loculus slabs appear exceptionally promising in this regard (they have undergone only limited, localized modern cleaning and still retain vestiges of earthen burial accretion) ${ }^{12}$, their present state of preservation is due to an extensive modern consolidation that to date has hampered investigation of their media. According to Museum records, in 1913 the front surfaces of all six of the monuments were consolidated using a brush application of "Solution No. 5", a mixture of glycerol and china wood oil with a lead oxide drying agent that was later marketed under the name Lithol ${ }^{13}$. This consolidant has imparted a yellow tinge to the front of the limestone monuments and is readily observable in microscopic examination. At present in the absence of any secure scientific data on the ancient media employed on the Metropolitan's objects or similar funerary monuments from Alexandria, it is probably best to simply make no assumptions or speculations about the ancient binding media, and to anchor discussion of the painting techniques and process based on direct examination.

Close scrutiny readily reveals the complexity and technical sophistication of the painting process on both the stelai and loculus slabs. The non-figural background areas were painted in flat, unmodulated fields of color with a uniform surface devoid of distinctive, legible brush strokes. The figural painting, in contrast, display numerous, sequential superimposed brush strokes with nuanced combinations of pigments to gradually build up and define color values. Early stages of the figural painting are often evident in abraded areas and display localized underpainting of a uniform color,

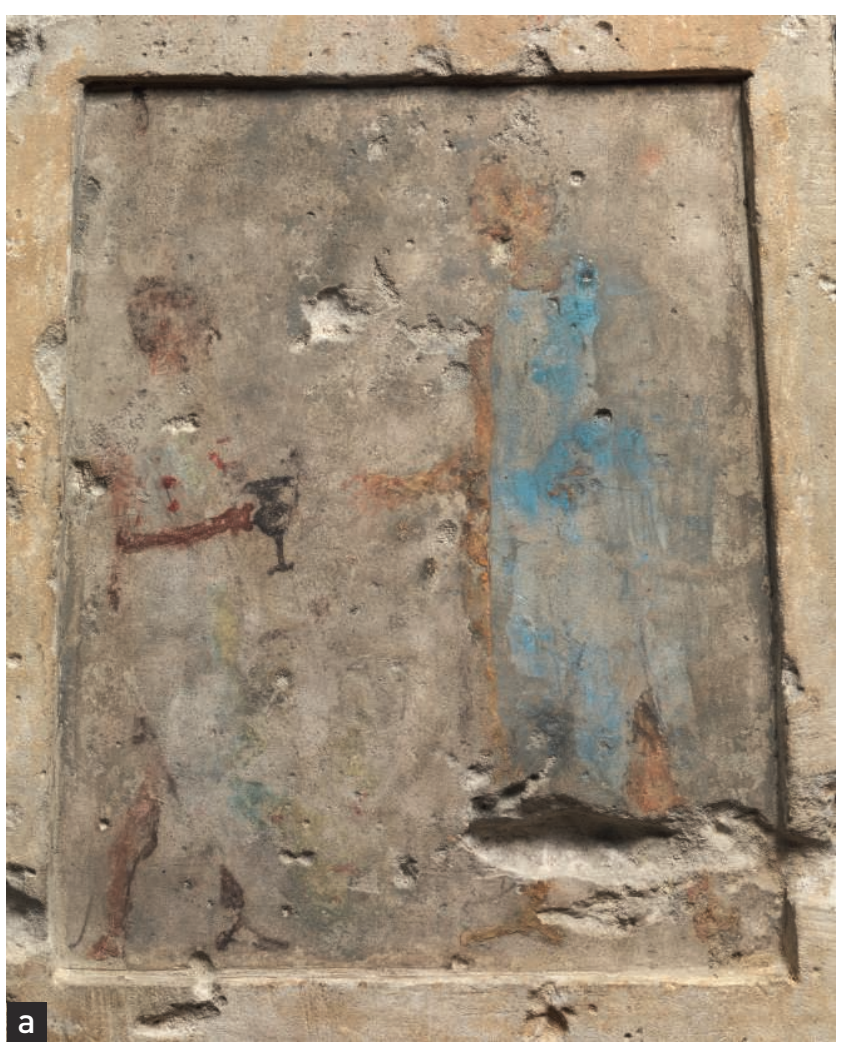

65

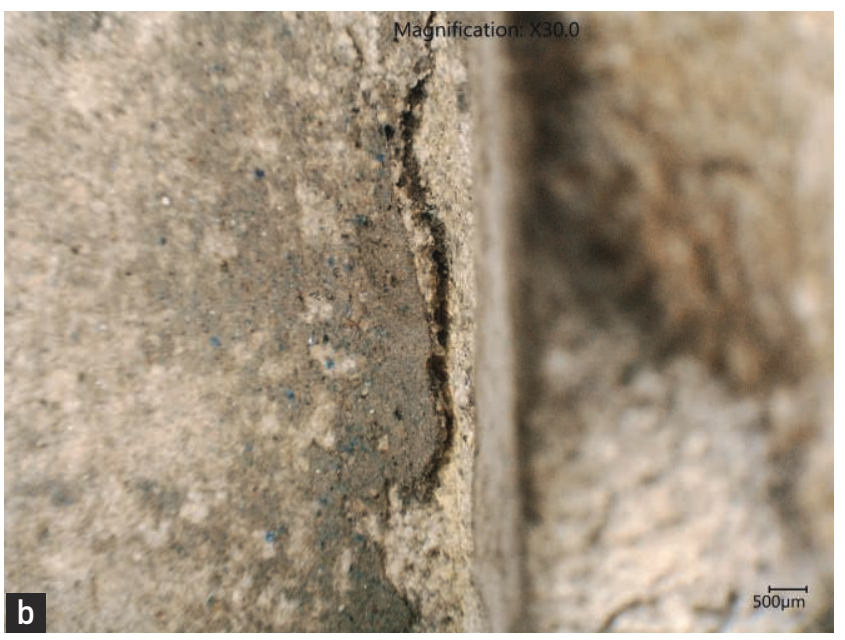

Fig. $6 a$-b. a. Picture panel of funerary slab with a soldier taking a kantharos from his attendant (fig. 1 e). ( ) The Metropolitan Museum of Art/B. Schwarz; b. Detail of lead white preparation layer visible below dark background color at right edge of picture panel, approximately $9 \mathrm{~cm}$ from the bottom edge of the picture panel, magnification 30x. Image taken in situ on panel using a Keyence digital microscope VHX-6000 with a VH-ZST dual objective low power (20-200x) zoom lens mounted on tripod. () The Metropolitan Museum of Art/D. Abramitis.

such as on the head of the seated male figure on the stele with the dexiosis scene (fig. 1 b, fig. 4 a, fig. 8 a-b). Here a localized base color of Egyptian blue was applied in the hair area and on the beard to impart richer, darker complex values to the dark brown and black painted strokes of the final hair color. On the adjacent flesh areas of the face, cinnabar was parsimoniously 

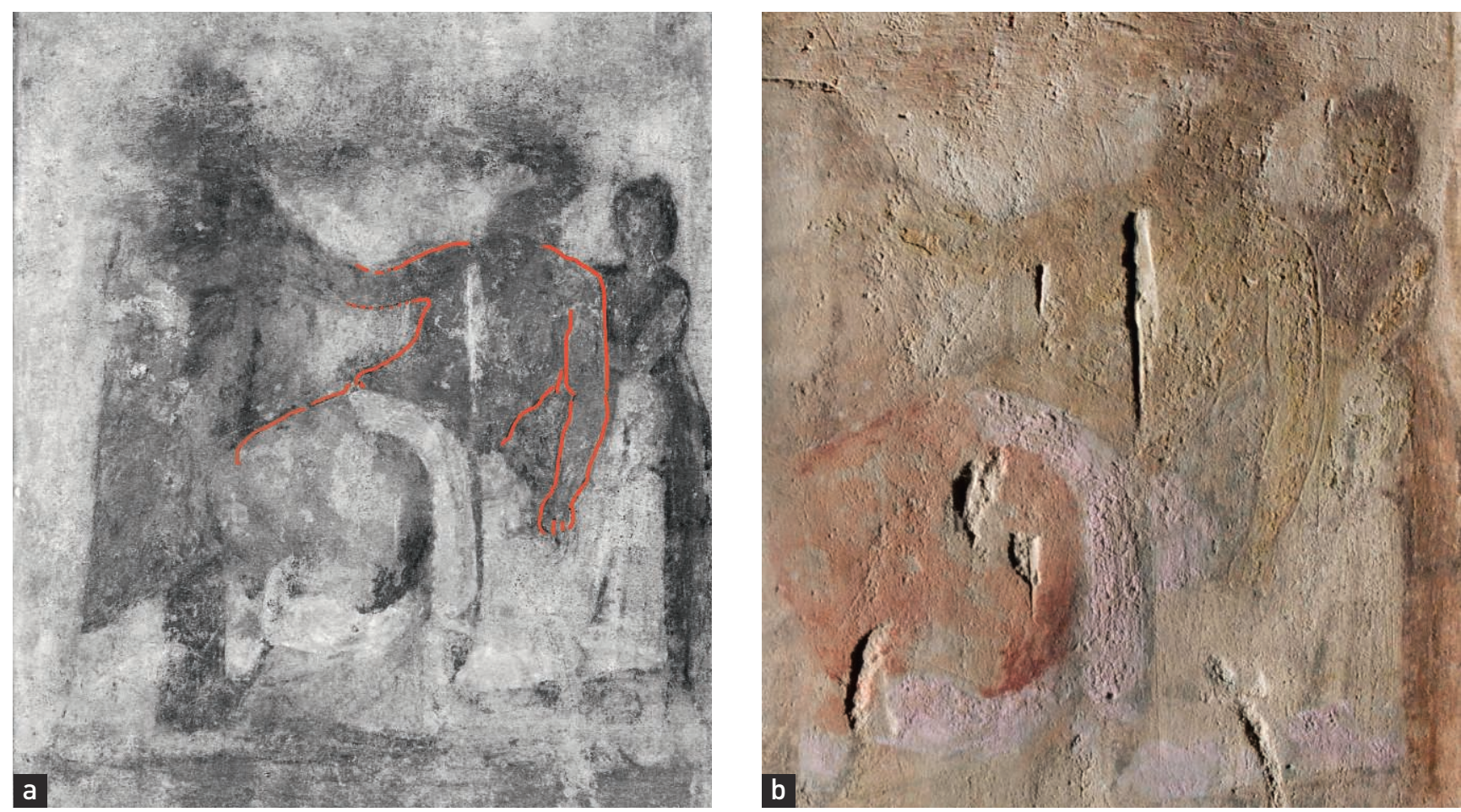

Fig. 7 a-b. Detail of stele with a woman in childbirth (fig. 1 a): a. Map of preliminary incision; b. Detail of incision in raking light. @ M. Abbe.

used to create base color highlights on the nose, ears and cheek for subsequent layers of painting.

Well-preserved areas of the figural painting display the gradual, additive, multiple application build-up of fine gradations of color through the layering of complex pigment mixtures. The result is thick impasto painting, such as the layering of folds, highlights and shadow lines on the standing female figure's drapery in the dexiosis stele (fig. 9 a-b). Similar complex gradations of color were obtained on flesh tones by varying the thickness of the paint's application in legible individual brush strokes. A result of this building-up of color is that the thick impasto of the figural elements project physically proud from the background color painting and thereby impart to the painting a notable three-dimensional quality.

\section{Pigments and their use}

The sole blue pigment evident in the paintings is Egyptian blue, which was used both to render solid blue color and extensively to modify the color values of other pigments as an admixture. In all of the paintings large, coarsely ground crystals (often visible to the naked eye) were used to best reflect the pigment's color. When rendering large areas of blue, such as on the long chlamydes of the mercenaries (fig. $1 \mathrm{c}-\mathrm{e}$ ), the pigment was mixed with lead white presumably as both an optical brightener and to enhance the opacity of the paint layer. A mixture of Egyptian blue and lead white was also painted in a thin layer over a yellow pigment to produce the only "green" on the Metropolitan's group of monuments on the fragmentary emblema of the shield of a mercenary that is held by his attendant (fig. 6 a, fig. 10 a). Egyptian blue was used extensively to deepen the color value of deep red, gray, brown, and black pigment mixtures. The one use of pure charcoal not mixed with Egyptian blue is found in the distinctly matte black kantharos on the loculus slabs of a Galatian mercenary (fig. 1 e). As previously noted, Egyptian blue was also used as a localized underpaint in hair and beard of the seated male figure on the dexiosis stele (fig. $8 \mathrm{a}-\mathrm{b}$ ).

In contrast to the use of a single blue colorant, the painting employed a range of red to reddish brown pigments. Ironbased earth pigments predominate and were used to generate a variety of tones. The purplish red, which was used in large amounts on the dexiosis stele, is a pure, very small-grained ochre clay. Red ochres, many rich in hematite, were used to render larger areas of bright red, such as in the mantle covering the lower body of the woman in childbirth on the large stele (fig. 1 a, fig. 3 a) and in the painting of details on the architectural frames of this stele and the loculus slabs. Brown umber, Egyptian blue and carbon black pigments were mixed with red ochres to achieve a wide range of dark reddishbrown tones, including the garments of the attendant figures on the aforementioned stele with a woman in childbirth and the rearing horse on the loculus slab (fig. $1 \mathrm{f}$ ). Minium was added with red ochre in a small number of mixtures, but is not found in isolated use. Cinnabar predictably was used very sparingly and only to highlight certain details, such as in the red facial highlights on the dexiosis stele. 

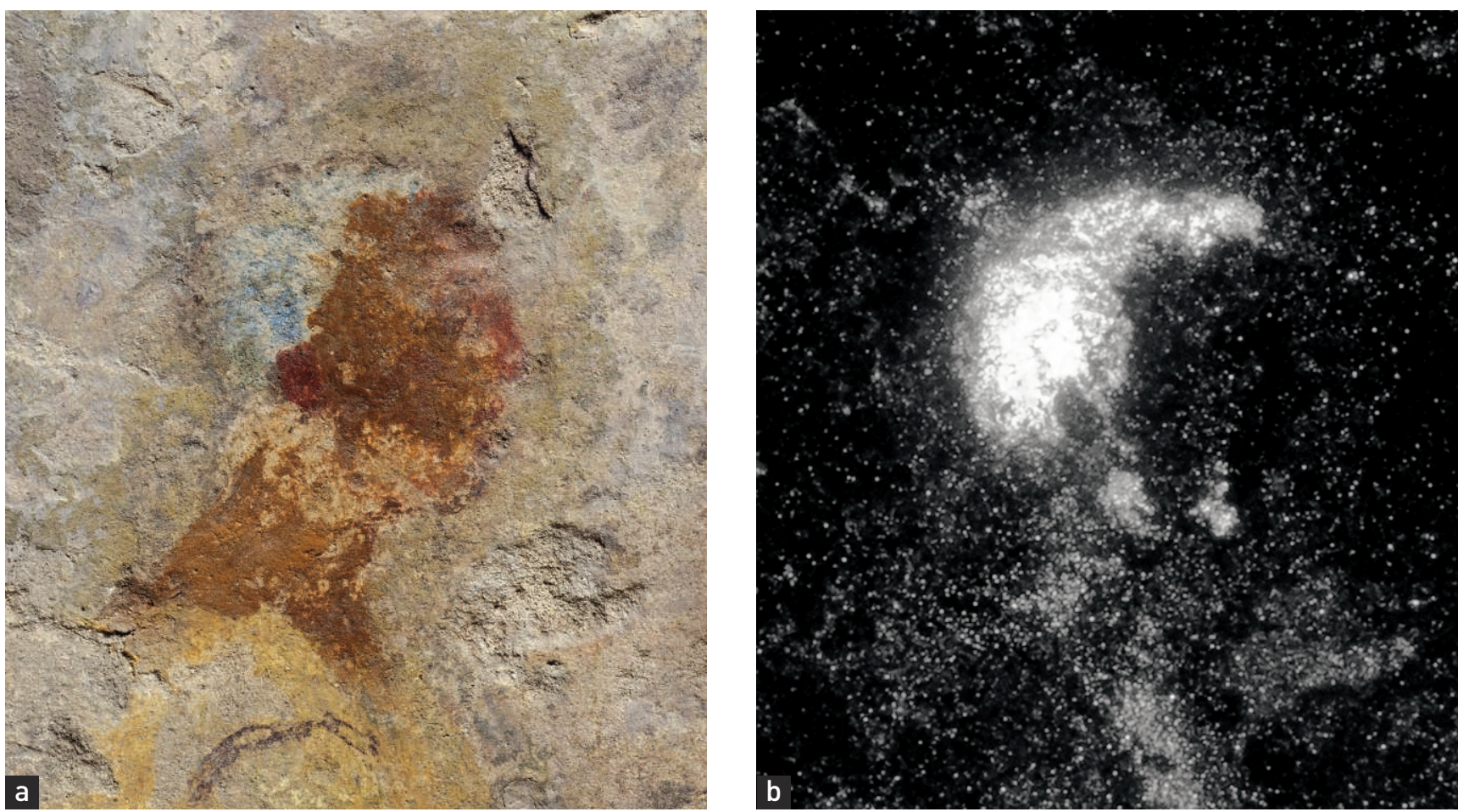

Fig. $8 a$ - $b$. Detail of seated man's head from stele with a seated man and two standing figures (fig. 1 b): a. Visible light. (C) The Metropolitan Museum of Art/B. Schwarz; b. Visible-induced infrared luminescence image (VIL). (C The Metropolitan Museum of Art/D. Abramitis.

Filling out the lighter end of the red palette is a pink found on the female garments, including the mantle on the stele with the woman in childbirth (fig. 3 a) and the garments on the girls on a loculus slab (fig. $1 \mathrm{c}$ ). This color was obtained through the use of an organic dyestuff, which fluoresces a pink-orange color in ultraviolet light, a vivid example being the wide folded pink border of the above mentioned mantle covering the woman dying in childbirth (fig. 3 c). Analysis by UV-visible absorption spectroscopy, surface enhanced Raman spectroscopy and examination by polarized light microscopy suggest that this pink is an anthraquinone colorant of made from the madder plant's root (either from the cultivated rubia tinctorum, or more likely the wild variety, rubia peregrina) that was precipitated onto a white clay to create a Madder lake pigment. This dye stuff was mixed with Egyptian blue to alter the color (fig. 3 a, d, fig. 10 b).

At least two types of yellow are evident in the palette of the paintings. Areas of the flesh rendered in yellow to yellow brown are yellow ochres that were frequently used in combination with red pigments and Egyptian blue to obtain darker flesh tones, such as the skin of the seated central figure on the dexiosis stele, and in the exposed skin of the woman dying in childbirth. Brighter yellow tones were achieved with a pigment containing arsenic, seen on details such as the drapery of both figures on the loculus slab with a rearing horse (fig. $1 \mathrm{f}$ ), and on the previously mentioned shield (fig. 6 a, fig. 10 c). This arsenic pigment is also used in combination with other pigments in the background color on the panels depicting a soldier with two girls (fig. $1 \mathrm{c}$ ) and a soldier standing at ease (fig. $1 \mathrm{~d}$ ). Pronounced peaks for arsenic obtained in in situ X-ray fluorescence readings initially suggested that the pigment on such areas were orpiment, however subsequent analyses by polarized light microscopy, X-ray microdiffraction and Raman spectroscopy identified the pigment as mimetite, a lead arsenate mineral $\left(\mathrm{Pb}_{5}\left(\mathrm{AsO}_{4}\right)_{3} \mathrm{Cl}\right)$.

The use of mimetite as a pigment was first reported by Philippe Walter in his study on the Alexandrian loculus slabs in the Louvre ${ }^{14}$. It has not been identified in the well-studied painting materials of Pharaonic Egypt and its use is attested in less than a handful of examples of Greek and Roman painting, namely on the façade of the Tomb of the Palmettes at Lefkadia from the first half of the 3rd century B.C. ${ }^{15}$, and on later Roman wall painting in Palmyra ${ }^{16}$ and a Roman marble sculpture from Utica ${ }^{17}$.

Mimetite is geologically rare and occurs almost exclusively in association with lead ores. Although there are multiple known sources of mimetite in the Mediterranean basin, including Sardinia, Tuscany, and Catalonia, it is notable that the largest Mediterranean source appears also to be one that was explored extensively in classical Antiquity, namely the silver-containing lead ores at Laurion in Attica, where mimetite occurs as a readily-visible yellow crust ${ }^{18}$. The ancient historical tradition of systemic mining and silver production from the galena ore at Laurion began in the late 6th century B.C. and peaked in the late 4th and 3rd centuries. Although limited mining continued through late Antiquity, the mass exploratory mining for silver at Laurion had largely ceased 

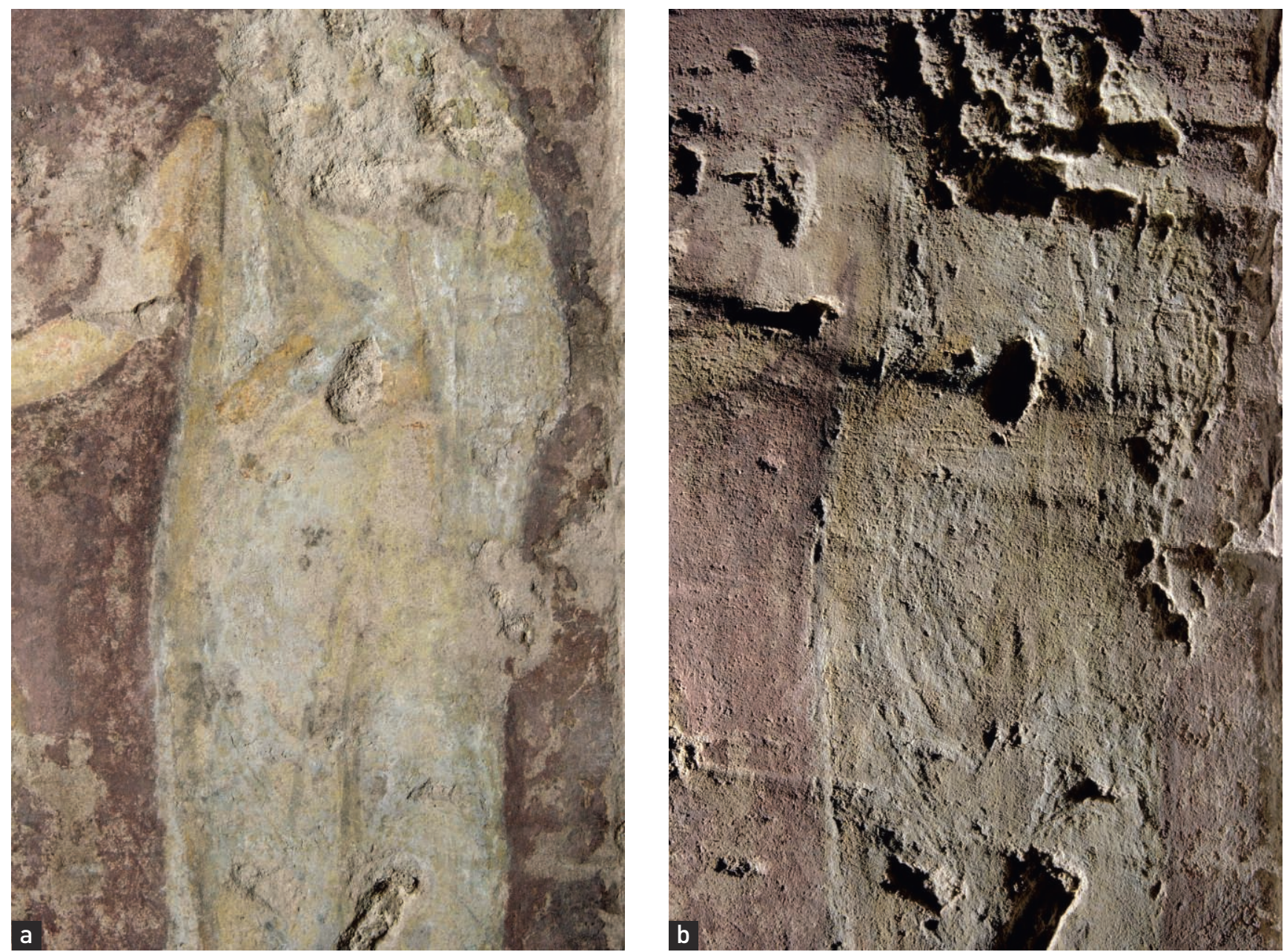

Fig. $9 a$-b. Detail of stele with a seated man and two standing figures (fig. 1 b), standing female figure in (a) regular and (b) raking light showing thick, multiple layered painting on drapery folds. @ M. Abbe.

by the 2 nd century B.C. Given its location and this ancient chronology, the mimetite encountered in the ancient mines at Laurion is certainly a possible, if not plausible, large scale source for this pigment. Thus, its origins may be akin to other much more rare and precious lead arsenate minerals such as the bright green conichalcite, found at Laurion and detected in the painted decoration on a late Archaic kore from Athens and in the painting of the facades and grave goods of royal tombs at Vergina in the 4th century B.C. ${ }^{19}$

The analysis of the mimetite present on the paintings in the Metropolitan Museum of Art suggests it has been applied as a pigment and is not a deterioration product as recently suggested in a Medieval mural painting ${ }^{20}$. The four samples of yellow from the Met paintings analyzed by X-ray microdiffraction found no traces of minerals typically associated with burial alteration, such as orpiment, realgar, pararealgar or arsenolite. It is notable that this geologically rare mineral is not parsimoniously employed on the loculus slabs at the Metropolitan (and the Louvre). It is combined with lead white to create bright yellow details (garments, etc.) and is used as the key constituent in the yellow background color on three loculus slabs. During the 3rd century B.C., this pigment was evidently widely used in Alexandria, and clearly merits more investigation. Further scientific examination is necessary to confirm our suggestion that the presence of mimetite on stelai from Alexandria relates to the trade of imported pigments, possibly from Athens. Regardless of its origins, the growing number of discoveries of this unexpected yellow pigment highlight how materials analysis can add new information to our historical understanding of the classical Greek palette.

\section{Color in context: broader trends and immediate experience}

Save for the extensive use of mimetite, the pigments, materials, and techniques of the paintings on the Metropolitan's painted limestone funerary monuments from Alexandria are attested elsewhere in Hellenistic art ${ }^{21}$. The group's distinctive use of lively, bright color, however, is notable and partakes in the enriched brilliant and sumptuous aesthetics of art and 

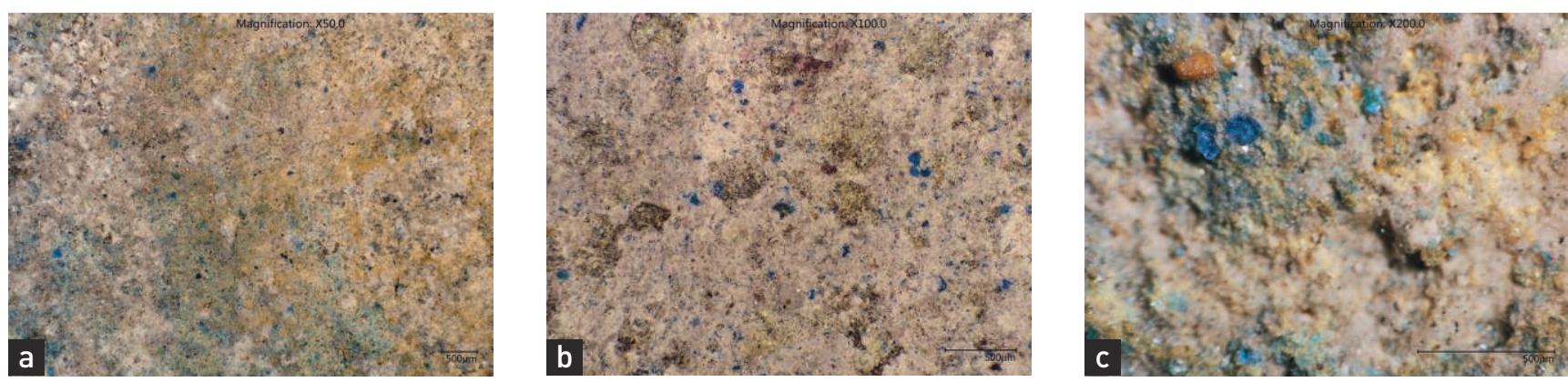

Fig. 10. a. Detail from center area of shield held by attendant (fig. 6 a) of "green" created from overlap of Egyptian blue and mimetite. Image taken in area of bright yellow along "green" edge, below the attendant's wrist, approximately $4.4 \mathrm{~cm}$ from the left edge of picture panel and $9.5 \mathrm{~cm}$ from the bottom of the picture panel, magnification 50x. b. Detail from lower area of pink dress on girl on right (fig. $1 \mathrm{c}$ ) showing Madder lake pigment mixed with Egyptian blue. Image taken approximately $6.3 \mathrm{~cm}$ from left edge of picture panel and $3 \mathrm{~cm}$ from bottom of picture panel, magnification 100x. c. Detail from lower area of shield held by attendant (fig. 6 a) showing mimetite and Egyptian blue taken in raking light. Image taken in the lower section of the shield in the "green" above the attendant's left foot, approximately $5.4 \mathrm{~cm}$ from left edge of picture panel and $4.7 \mathrm{~cm}$ from bottom edge of picture panel, magnification 200x. All images taken in situ on panels using a Keyence digital microscope VHX-6000 with a VH-ZST dual objective low power (20-200x) zoom lens mounted on tripod. All images $\odot$ The Metropolitan Museum of Art/D. Abramitis.

especially painting in early and middle Hellenistic periods. To contemporaries, such vivid, color-rich painting had a distinctly modern and contemporary flair. If and to what degree the engagingly luminous coloration of the Metropolitan's monuments was distinctive of Alexandria and Ptolemaic Egypt remains unclear based on our limited evidence, even if, as Agnes Rouveret has suggested, the region was subsequently associated with such colorful displays ${ }^{22}$.

Regardless of such broader trends, these bright colorful paintings were designed to be viewed in a specific ancient display context: the dimly lit subterranean hypogea tombs of Alexandria, where their appearances would have been visually transformed, and may have evoked a different, richer material universe. In this darkened realm, their bright, conspicuously colorful painted surfaces, acquired a luminous and precious materiality. The large grains of pigment appeared glittering, almost gem-like. The thick chiaroscuro impasto of the figural painting became animated under flickering golden illumination so that the figures' active postures and telling gestures seemingly sprang momentarily to life. Intended to be viewed intimately, with localized, almost spot-like lighting, these scenes appeared readily legible, but individually varied and specific enough to hold the viewer's eye and interest. Distilling the essence of their subject, the colorful rhetoric of such brilliant, eye-catching painting was like that of funerary epigrams: it made a visual appeal to the living in the hopes that they would pause, stop, look, and learn and, in turn, think upon the deceased lest they be forgotten.

Color, painting technique, composition and lighting were interwoven in the contextually designed viewing of these paintings. Understood in their ancient context, these rare well-preserved survivals of painting from Ptolemaic Egypt demonstrate more than the technical sophistication of their otherwise unknown painters in Alexandria in the late 4th and 3rd centuries B.C. They evince how the non-elite of the Ptolemaic capital patroned the culturally celebrated and esteemed artistic craft of painting in this age to create their own meaningful, individual images of eternal commemoration.

Table 1. Painting materials identified on the Alexandria funerary monuments

\begin{tabular}{|c|c|}
\hline Pigment/Colorant & Methods of identification \\
\hline \multicolumn{2}{|l|}{ Blue } \\
\hline Egyptian blue & p-XRF, PLM, Raman, XRD, VIL \\
\hline \multicolumn{2}{|l|}{ Red } \\
\hline Red ochre & p-XRF, PLM, Raman \\
\hline Haematite & p-XRF, PLM, Raman \\
\hline Red lead & p-XRF, PLM, Raman \\
\hline Cinnabar & p-XRF, PLM, Raman \\
\hline Alizarin-based lake & PLM, Raman, UVS \\
\hline \multicolumn{2}{|l|}{ Yellow } \\
\hline Yellow ochre & p-XRF, PLM, Raman \\
\hline Mimetite & p-XRF, PLM, Raman, XRD \\
\hline Raw umber & p-XRF, PLM, Raman \\
\hline \multicolumn{2}{|l|}{ White } \\
\hline Cerussite/hydrocerussite & p-XRF, PLM, Raman, XRD \\
\hline Whiting/chalk & p-XRF, PLM, Raman, XRD \\
\hline \multicolumn{2}{|l|}{ Black } \\
\hline Charcoal black & PLM, Raman \\
\hline
\end{tabular}

Abbreviations: PLM: Polarized light microscopy, Raman: Raman spectroscopy, UVS: Ultraviolet-visible absorption spectroscopy, VIL: Visible-induced luminescence, XRD: X-ray diffraction spectroscopy, p-XRF: portable X-ray fluorescence spectroscopy. 


\section{Acknowledgments}

The authors are grateful to Seán Hemingway, Carlos A. Picón, Elizabeth J. Milleker, and Joan R. Mertens, Curators in the Department of Greek and Roman Art, for the invitation to undertake this study and their invaluable suggestions throughout. We would like to thank Marco Leona, James H. Frantz, and Federico Carò of the Department of Scientific Research for generous technical expertise, and Lisa Pilosi and Lawrence Becker of Objects Conservation.

\section{Notes}

1. Site description: Merriam, 1887, p. 261-262, and the letter from E. E. Farman reproduced in Cook, 1966a, p. 34

2. Necropoleis: McKenzie, 2007, p. 28-29, 71-74; Venit, 2002, p. 22-24; Bernand, 1966, p. 213-216. p. 34

3. Brown, 1957. Quote: Cook, 1966a

4. Venit, 2002, p. 20-21, 26, 156, 194; Rouveret, Walter, 2004, p. 29-91.

5. Cook, 1966a ; Cook, 1966b, p. 15-18; Rouveret, Walter, 2004, p. 29-34.

6. Similar material: Rouveret, Walter, 2004, p. 29-92; Brown, 1957, p. 4-52, 83-95.

7. Demetrias: Preusser, von Graeve Wolters, 1981; Batziou-Efstathiou, 2002, p. 40-47; Vergina: Drougou, SaatsoglouPaliadeli, 1994, p. 33-39; Brecoulaki, 2006 , p. 149-159; Chersonessos: Posamentir, 2011

8. Portable X-ray fluorescence spectroscopy was conducted by the authors and Marco Leona of the Department of Scientific Research using a Bruker Tracer III-V portable spectrometer with a Re or $\mathrm{Rh}$ tube and a Peltier cooled Ag-free detector. Spectra generally were obtained at $40 \mathrm{kV}$ and $1.3 \mathrm{~mA}$ with acquisition times of $90-120$ or longer depending on the sample area and its geometry; $\mathrm{Ti}$ and $\mathrm{Cu}-\mathrm{Ti}$-Al filters to enhance detection of select elements. X-ray microdiffraction analysis was performed on several samples of pigments, grounds and possible accretionary materials. These analyses were carried out by James H. Frantz of the Department of Scientific Research, with a Rigaku Dmax/Rapid microdiffraction instrument using $\mathrm{Cu} \mathrm{Ka}$ radiation and an $800 \mathrm{~mm}$ collimator with the samples rotated about two axes during the exposures.

9. Open-architecture X-ray diffraction analysis was performed in March of 2006 by James H. Frantz on a sample of the stone fabric removed as a scraping from the interior wall of a modern drill hole on the underside of the stela. The sample yielded a clear pattern with more than thirty lines between $10^{\circ}$ and $80^{\circ} 2 \theta$ using $\mathrm{Cu} \mathrm{Ko}$ radiation. An unrestricted search undertaken at that time of the current ICDD PDF-2 database using Jade 7.0 explicitly resolved the pattern as representing a mixture of calcite and aragonite with both phases present in significant proportions.
X-ray fluorescence analysis of the same sample yielded spectra dominated by the lines of calcium and strontium. The XRD and $\mathrm{p}$-XRF results together with the texture and fossiliferous character of the stone led to an identification of a strontium-bearing aragonitic limestone.

10. Rouveret, Walter, 2004, p. 140-141.

11. Rouveret, Walter, 2004, p. 142-144.

12. Modern retouching of the painting appears limited to tinted inpainting containing zinc white on the larger stelai (04.17.1-.2).

13. Becker, Schorsch, 2010, p. 20-21. $\mathrm{X}$-ray fluorescence readings taken in consolidated areas of the stone without ancient painting yield small concentrations of lead probably attributable to the leadbased drying agent of the consolidant.

14. Rouveret, Walter, 2004, p. 142.

15. Brecoulaki, 2010, p. 106, 109, 116

16. Buisson, Burlot, Eristov, Eveno, Sarkis, 2014, p. 1041-1043.

17. Kopczynski, De Viguerie, Neri, Nasr, Walter, Bejaoui, Baratte, 2017, p. 147-152.

18. Skarpelis, Argyraki, 2009; Gelaude, van Kalmthout, Rewitzer, 1996.

19. Twilley, 2002, p. 174; Brecoulaki, Perdikatsis, 2002, p. 153; Brecoulaki, Sotiropoulou, Katsifas, Karydas, Kantarelou 2014, p. 13-14, postulate a local Macedonian source.

20. Hradil, Hradilová, Bezdička, Švarcová, Čermáková, Košařová, Němec, 2014, p. 854-858, postulate the presence of mimetite on Medieval mural painting as a deterioration product of orpiment in the presence of lead rich sources found in combination with other deterioration products including realgar, pararealgar or arsenolite.

21. General overview: Kakoulli, 2009.

22. Rouveret, Walter, 2004, p. 147-148; Rouveret, Walter, 2007, p. 131.

\section{Bibliography}

Batziou-Efstathiou A., 2002, Demetrias, Archaeological Receipts Fund, Athens.

Becker L., Schorsch D., 2010, "The Practice of Objects Conservation in The Metropolitan Museum of Art (18701942)", Metropolitan Museum Studies in Art, Science, and Technology, 1, p. 11-37.
Bernand A., 1966, Alexandrie la Grande, Arthaud, Paris.

Brecoulaki H., 2006, La Peinture funéraire de Macédoine. Emplois et fonctions de la couleur $I V^{e}-I I^{e}$ s. av. J.-C., National Hellenic Research Foundation, Mélétèmata 48, KERA, Athens.

Brecoulaki H., 2010, "A Scientific Investigation on the Painted Decoration of the Tomb of the Palmettes", in K. Rhomiopoulou, B. Schmidt-Dounas, Das Palmettengrab in Lefkadia, Mitteilungen des Deutschen Archäologischen Instituts, Athenaische Abteilung, 21. Beiheft, Mainz am Rhein, p. 102-118.

Brecoulaki H., Perdikatsis V., 2002, “Ancient Painting on Macedonian Funerary Monuments, IV-III Centuries B.C.," in M.-A. Tiverios, D. Tsiafakis (eds.), Color in Ancient Greece. The role of color in ancient Greek art and architecture (700-31 B.C.). Proceedings of the conference held in Thessaloniki, 12th-16th April 2000, Aristotle University of Thessaloniki, Thessaloniki, p. 147-154.

Brecoulaki H., Sotiropoulou S., Katsifas C., Karydas A. G., Kantarelou V., 2014, "A Microcosm of Colour and Shine. The Polychromy of Chryselephantine Couches from Ancient Macedonia", in B. Bourgeois (ed.), Therapeia. Polychromie et restauration de la sculpture dans l'Antiquité, Technè 40, p. 9-22.

Brown B. R., 1957, Ptolemaic Paintings and Mosaics and the Alexandrian Style, Archaeological Institute of American, Cambridge, Mass.

Buisson N., Burlot D., Eristov H., Eveno M., Sarkis N., 2014, "The Tomb of the Three Brothers in Palmyra: The Use of Mimetite, A Rare Yellow Pigment, in a Rich Decoration", Archaeometry 57, p. 1025-1044.

Cook B. F., 1966a, Inscribed Hadra Vases in the Metropolitan Museum of Art, Metropolitan Museum of Art, New York

Cook B. F., 1966b, "An Alexandrian TombGroup Re-Examined”, American Journal of Archaeology 70, p. 325-330.

Drougou S., Saatsoglou-Paliadeli Ch., 1994 Vergina: The Great Tumulus, Aristotle University of Thessaloniki, Thessaloniki. 
Gelaude P., van Kalmthout P., Rewitzer C., 1996, Laurion: the minerals in the ancient slags, Janssen Print, Nijmegen.

Hradil D., Hradilová J., Bezdička P., Švarcová S., Čermáková Z., Košařová V., Němec I., 2014, "Crocoite $\mathrm{PbCrO} 4$ and mimetite $\mathrm{Pb} 5$ (AsO4)3Cl: rare minerals in highly degraded mediaeval murals in Northern Bohemia”, Journal of Raman Spectroscopy, 45, p. 848-858.

Kakoulli I., 2009, Greek Painting Techniques and Materials from the Fourth to the First Centuries B.C., Archetype, London.

Kopczynski N., De Viguerie L., Neri E., Nasr N., Walter P., Bejaoui F., Baratte F., 2017, "Polychromy in Africa Proconsularis: Investigating Roman statues using X-ray fluorescence spectroscopy", Antiquity 91, p. 139-154.

McKenzie J., 2007, The Architecture of Alexandria and Egypt, c. 300 B.C.-A.D. 700, Yale University Press, New Haven. Merriam A. C., 1887, "Painted Sepulchral
Stelai from Alexandria”, The American Journal of Archaeology and of the History of the Fine Arts 3, p. 261-268.

Posamentir R., 2011, The Polychrome Grave Stelai from the Early Hellenistic Necropolis (Chersonesan Studies 1, edited by J. C. Carter), University of Texas Press, Austin.

Preusser F., von Graeve V., Wolters C., 1981, "Malerei auf griechischen Grabsteinen: Technische und naturwissenschaftliche Aspekte eines archäologischen Materials", Maltechnik-Restauro, Internationale Zeitschrift für Farb- und Maltechniken, Restaurierung und Museumsfragen, 87 (1), p. 11-34.

Rouveret A., Walter P. (collab.), 2004, Peintures grecques antiques : la collection hellénistique du musée du Louvre, Fayard/ musée du Louvre Éditions, Paris.

Rouveret A., Walter P., 2007, "Couleur et matières dans les peintures hellénistiques du musée du Louvre”, in S. Descamps-Lequime (ed.), Peinture et couleur dans le monde grec antique, musée du Louvre Éditions /5 Continents Éditions, Milan, p. 121-131.

Skarpelis N., Argyraki A., 2009, "Geology and Origin of Supergene Ore at the Lavrion Pb-Ag-Zn Deposit, Attica Greece", Resource Geology, 59, p. 1-14.

Twilley J., 2002, "Pigment Analyses for the Grave Stelae and Architectural Fragments from Chersonesos," in M.-A. Tiverios, D. Tsiafakis (eds.), Color in Ancient Greece. The role of color in ancient Greek art and architecture (700-31 B.C.). Proceedings of the conference held in Thessaloniki, 12th-16th April 2000, Aristotle University of Thessaloniki, Thessaloniki, p. 171-178.

Venit M. S., 2002, Monumental Tombs of Ancient Alexandria, Cambridge University Press, Cambridge. 